\title{
AMERICAN TELEMEDICINE ASSOCIATION: FIRST CHINA (TIANJIN) INTERNATIONAL TELEMEDICINE TECHNOLOGY EXHIBITION
}

\author{
JORDANA BERNARD
}

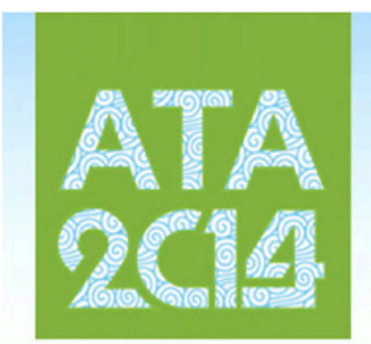

\section{THE FIRST GHINACTIANJIN] INTERNATIONAL TELEMEDICINE TECHNOLOGY EXHIBITIONO Binhai International Convention \& Exhibition Center 28th-30th October,2014 首届中国（天津）国际远程医疗技办展览会 \\ 2014年10月28日-30日 天津滨海国际会展中心}

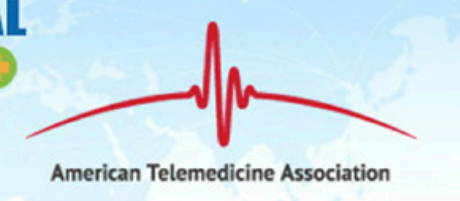

The three day event will feature keynote sessions, concurrent discussion forums, exhibits (e.g., telemedicine, information technology, mHealth), a venture summit, meet-and-greet sessions for international and domestic companies for potential business collaboration, and policy discussions on China healthcare.

For registration information: http://www.atacn.org/en/ 
